\title{
The dynamics of red fox (Vulpes vulpes) and brown hare (Lepus europaeus) populations in the Vojvodina region (Serbia) in relation to rabies vaccination
}

\author{
Igor Ponjiger*, Zoran Ristić, Vladimir Marković, Milosava Matejević, \\ and Milutin Kovačević
}

Department of Geography, Tourism and Hotel Management Faculty of Sciences, University of Novi Sad, Novi Sad, Serbia

PONJIGER, I., Z. RISTIĆ, V.MARKOVIĆ, M. MATEJEVIĆ, M. KOVAČEVIĆ: The dynamics of red fox (Vulpes vulpes) and brown hare (Lepus europaeus) populations in the Vojvodina region (Serbia) in relation to rabies vaccination. Vet. arhiv 89, 839-850, 2019.

\section{ABSTRACT}

Certain aspects of the red fox (Vulpes vulpes Linnaeus, 1758) and brown hare (Lepus europaeus Pallas, 1778) population dynamics in the Autonomous Province Vojvodina (Serbia) were analysed on the basis of the available data from 1978-2015. Red fox culling was taken into account as a factor affecting the abundance of brown hares. In that period, during regulated hunts a total of 399,976 foxes were culled and the annual average was $10,526(\mathrm{SD}=2985)$. Brown hare spring counts showed fluctuations during the research period and showed a declining trend in the number of individuals. The red fox was selected for the study as the most abundant predator in this area, having the most impact on brown hares. Also, in 2010 a nationwide vaccination campaign against rabies was conducted, leading to an increase in the numbers of red foxes. However, while this led to a rise in the numbers of red foxes, the cull remained nearly the same in the following years. Analysis of the relationship between the numbers of brown hare and the red fox cull in 1978-2009 and 2010-2015 showed a significant difference in their ratio. This study shows that the numbers of red fox increased significantly following the rabies vaccination. Consequently, this is a significant factor that is affecting the brown hare population. Also, it is evident that the red fox cull needs to be increased in order to maintain the natural balance.

Key words: brown hare; red fox; rabies; correlation

\section{Introduction}

The brown hare (Lepus europaeus Pallas, 1778) population has been declining in Serbia (BEUKOVIĆ et al., 2009; POPOVIĆ et al., 2014) and most of Europe since the 1960s. A

\footnotetext{
${ }^{*}$ Corresponding author:

Igor Ponjiger, Department of Geography, Tourism and Hotel Management, Faculty of Sciences, University of Novi Sad; Dositeja Obradovića 3, 21000 Novi Sad, Serbia, E-mail: igor.ponjiger@dgt.uns.ac.rs
} 
I. Ponjiger et al.: The dynamics of red fox (Vulpes vulpes) and brown hare (Lepus europaeus) populations in the Vojvodina region (Serbia) in relation to rabies vaccination

number of factors has been listed as reasons for this. Some of the include intensification of agriculture, climate change, changes in the number of predator populations etc. (SMITH et al., 2005). However, there has been no agreement about whether is it the combination of all of these factors, and there is still no accurate quantification of the individual contribution of each of these factors. Taking this into account, it is clear that there are areas where the brown hare is vulnerable. Therefore an analysis of all the factors affecting the population is crucial.

The brown hare, a common steppe type of game, has adapted in modern days to agricultural ecosystems which cover most of the study area in Vojvodina (Serbia) (ŠELMIĆ, 1997; JENNINGS et al., 2006). Also, the brown hare is a species with a very important role in the hunting economy of this area (VAPA and ŠELMIĆ, 1997), therefore it is crucial to study and monitor the population. Many papers about the status of brown hare in Serbia show the effect of previous management practices and climate factors on the population (BEUKOVIĆ et al. 2013; POPOVIĆ et al. 2014). To some extent they explain certain factors of the brown hare's decline, but other aspects need to be taken into account.

TAPPER et al. (1996) and GORETZKI et al. (1999) noted that predators have a strong effect on the population of small game. It is known that the brown hare is part of the diet of most of the carnivores that inhabit the study area. One of the most recognized causes of the brown hare's decline is predation (SCHMIDT et al., 2004; PANEK et al., 2006). The numbers of predators, mainly foxes, have frequently been recognized as an explanation for the decline in hare numbers (SLAMEČKA et al., 1997; PANEK and KAMIENIARZ, 1999). Also, the general trend is that the density of foxes is increasing in most of Europe, mainly due to rabies vaccination, a reduction in hunting and increasing urbanisation (GOSZCZYŃSKI et al. 2008).

The red fox is a predator for which it is known that the brown hare is a significant part of its diet, and it has a major impact on its population. Rodents, lagomorphs, birds, carrion, insects and fruits are considered the main food of red foxes (JEDDRZEJEWSKI et al., 1989; LINDSTROM, 1989; DONCASTER et al., 1990). The proportion of hares in the red fox's diet differs throughout Europe, and depends on habitat conditions and the proportion of available food sources. Red fox scat analysis found remains of brown hare in $29 \%$ of cases in Croatia (KRAPINEC et al., 2010). Also it was discovered that predation pressure of red foxes on brown hare increased over the last century (HELL et al., 1997). All this leads to the conclusion that the abundance of red fox has had a major impact on the brown hare population living in the same area.

The aims of this study were to determine the extent of the red fox's impact on the brown hare population in the Vojvodina region of Serbia, and to compare 
I. Ponjiger et al.: The dynamics of red fox (Vulpes vulpes) and brown hare (Lepus europaeus) populations in the Vojvodina region (Serbia) in relation to rabies vaccination

the relationship between the densities of these species before and after the rabies vaccination.

\section{Materials and methods}

Study area. The Republic of Serbia has a total of 8,828,528.29 ha of hunting areas. The northern part of Serbia, the Autonomous Province of Vojvodina has a total $2,152,695.60$ ha of areas considered as hunting grounds. Hunting associations manage 120 hunting grounds with an area of 2,006,910.85 ha (The Law on Game and Hunting, Official Gazette of RS, 18/2010).

The subject of this research were hunting grounds managed by hunting associations, mainly because of the similarity of habitat conditions and game managed (Fig. 1). Besides two low mountains Fruška Gora $(539 \mathrm{~m})$ and Vršačke Planine (641 m), Vojvodina is mostly a lowland, flat region. The largest part of the area is agricultural land which covers about $83.3 \%$ of the total area, while forests cover about $6.7 \%$. Infertile land accounts for about 10\% (built-up areas and inland water areas) (Statistical Yearbook of the Republic of Serbia, 2017). This type of agricultural habitat is mostly suitable for managing roe deer, brown hare, pheasant and grey partridge, which are the most abundant species in these hunting grounds.

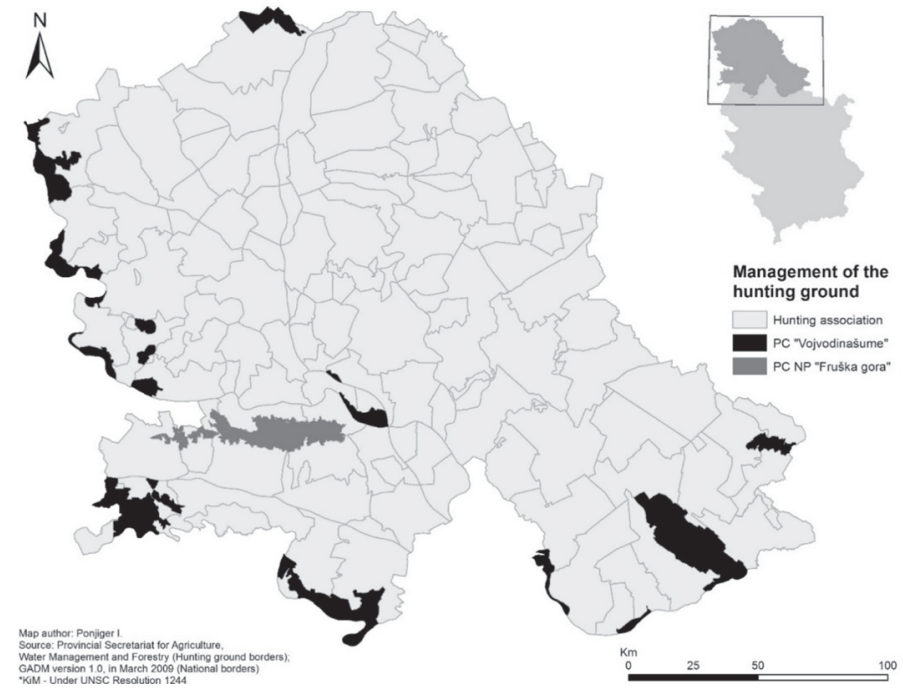

Fig. 1. The area of AP Vojvodina and dispersal of hunting grounds managed by hunting associations that are the subject of the research 
I. Ponjiger et al.: The dynamics of red fox (Vulpes vulpes) and brown hare (Lepus europaeus) populations in the Vojvodina region (Serbia) in relation to rabies vaccination

Other areas and hunting grounds are managed by the public enterprise "Vojvodina šume" and the Fruška gora National Park. These hunting grounds were excluded from the research because of the differences in the habitat conditions, and the type of game and management. These hunting grounds are mainly heavily forested areas and manage different types of game, such as red deer, wild boar, fallow deer and mouflon. Also, these hunting grounds are mostly fenced.

Data. The aim of the paper was to find the correlation between numbers of red fox and brown hare and the changes in the dynamics of this relationship since 2010 when nationwide rabies vaccination was carried out. This was done by using the data on the annual red fox cull and the annual number of brown hare. Data on the red fox cull was obtained from the Hunting Association of Vojvodina, based on 38 hunting seasons in the period from 1978 to 2015 . Since these are data from regulated hunts, it was assumed that the cull was conducted according to the hunting plans. Although it has changed over the years, currently the fox hunting season is from 1.1. - 31.12., or throughout the entire year.

Data on brown hare were also obtained from the Hunting Association of Vojvodina based on hare spring counts in the same period. Spring counts are carried out annually at the end of February and throughout March in all of the hunting grounds. Hare numbers in individual hunting grounds are determined by means of the strip-transect method. Three transects are chosen to include all environmental variations and areas with the highest and lowest hare densities, in order to have an average representation of the entire hunting ground. Areas being counted, the transects, must cover a minimum of $10 \%$ of the surface area of the entire hunting ground. On this basis the number of brown hares can be estimated.

Statistical analysis. All analyses were performed using the IBM SPSS (ver. 23). Pearson's correlation coefficient $r$ and linear regression models were applied to assess the relationship between the annual red fox cull and the annual brown hare numbers. To generate predictive equations for the significance, non-significant variables were removed from the final regression model.

\section{Results}

The annual red fox cull varied in the 1978-2015 period observed. However, a negative trend could be seen (Fig. 2.) where the cull was significantly higher in the first third of the study period. It ranged from 18,067 individuals in 1978 to only 3,856 foxes in 1992 . This all-time low can be mainly attributed to the war in the former Yugoslavia leading to a much lower cull. The second lowest recorded cull was during the 2013 hunting season with 6,750 individuals.

The average red fox cull during the observed period was 10,526 (Std. Deviation 2985.37) or 5.24 individuals/1000 ha. Research by ŠELMIĆ (1996) noted that the average spring density of red foxes was 1.08 individuals/100 ha in the Vojvodina region. Over the 
I. Ponjiger et al.: The dynamics of red fox (Vulpes vulpes) and brown hare (Lepus europaeus) populations in the Vojvodina region (Serbia) in relation to rabies vaccination

38 fox hunting seasons recorded, the cull has, for the most part, been decreasing. In the 70 s and 80 s the fox cull was mostly stable, with 13,864 individuals culled on average. While there were certain fluctuation in the fox population, it was considered to be stable. In the 00s and 10s the average annual cull dropped to 8,799.6. With the changes in the fox population dynamics after the vaccination, it may be said that it had a major influence on all types of game in the same habitat. This study shows the direct impact on brown hare as a species already suffering from decreasing numbers caused by a number of factors.

The average population of brown hare during the 1978-2015 period was 252,121 (Std. Deviation 36,763.34). On this basis it was calculated that the average density for the same period was 12.6 individuals/100 ha. During the observed period, the population of brown hare showed fluctuations and a cyclical pattern for the most part. This may be seen by comparing the average population seen in the spring counts. At the end of $70 \mathrm{~s}$, and in the $80 \mathrm{~s}$ and $90 \mathrm{~s}$, the average annual number of brown hare was 254,765. Similarly, in the $00 \mathrm{~s}$ and $10 \mathrm{~s}$ the combined average result is 250,348 individuals. As can be seen, there was only a slight decrease. However, looking at the records from 2010 onwards, a sharp decline in hare numbers is evident. Brown hare reached its record all-time low in 2014, with 154,990 individuals counted during the spring count.

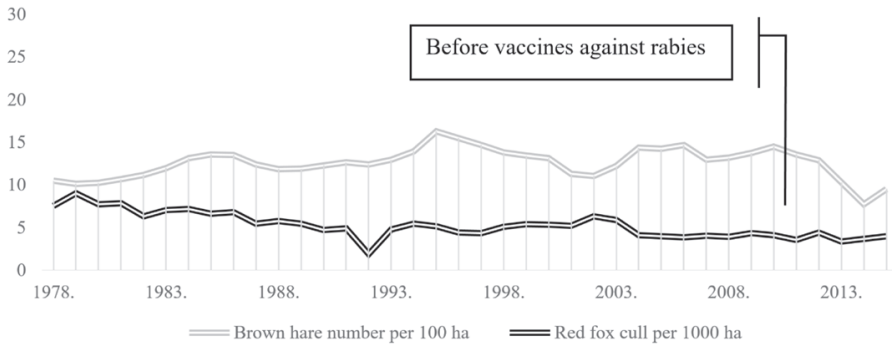

Fig. 2. Population of brown hare and the red fox cull in the Vojvodina region (hunting grounds managed by hunting associations) for the $1978-2015$ period

A consistent increase in fox numbers since 2010 has been reported in most of the study area. While there are no official statistics, it is assumed that fox numbers increased dramatically. This was confirmed by conversations with many hunting ground managers. The cull was not increased following the vaccination mainly because average hunters lack interest in hunting predators, in this case foxes.

Comparing the period before and after the vaccination, it may be seen that the number of brown hare has decreased. Also comparing the hare counts (t-1) and the annual fox cull using the Pearson correlation, gives the results seen in Table 1. 
I. Ponjiger et al.: The dynamics of red fox (Vulpes vulpes) and brown hare (Lepus europaeus) populations in the Vojvodina region (Serbia) in relation to rabies vaccination

Table 1. Results of correlation analysis of brown hare numbers and the annual fox cull

\begin{tabular}{|l|c|c|c|}
\hline Observed period & $\mathrm{n}$ & $\mathrm{r}$ & $\mathrm{P}$ \\
\hline $1978-2015$ & 38 & -0.136 & 0.414 \\
\hline $1978-2010$ & 33 & -0.531 & 0.001 \\
\hline $1978-2010^{1}$ & 32 & -0.590 & 0.000 \\
\hline
\end{tabular}

${ }^{1}$ Hunting season 1992 excluded. $\mathrm{n}$ - Number of hunting seasons; r - Correlation coefficient; P - Probability

A strong negative correlation may be seen when comparing the hare population and fox cull up until 2010. This may be explained by taking into account the fact that when the number of foxes is higher, the number of hares is lower. Also, a higher cull leads to the assumption that the number of foxes is high, hence a lower hare population. HELL et al. (1997) also discovered a significant negative correlation between the annual red fox cull and the number of brown hares $(\mathrm{r}=-0.652 ; \mathrm{P}<0.01)$.

Correlation analysis showed a strong connection between the two variables (fox cull and brown hare population). In order to determine exactly to what extent the fox cull influences the number of brown hares a linear regression analysis was carried out.

Table 2. Results of linear regression analysis, with brown hare numbers as the dependent variable - $y$ (or criteria), and the annual fox cull as the independent variable - $\mathrm{x}$ (predictor)

\begin{tabular}{|l|c|c|c|}
\hline Observed period & $\mathrm{n}$ & $\mathrm{R}^{2}$ & $\mathrm{~F}$ \\
\hline $1978-2015$ & 38 & 0.019 & $<1$ \\
\hline $1978-2010$ & 33 & 0.282 & 12.18 \\
\hline $1978-2010^{1}$ & 32 & 0.348 & 16.03 \\
\hline
\end{tabular}

${ }^{1}$ Hunting season 1992 excluded. N - Number of hunting seasons; $\mathrm{R}^{2}$ - Explained variation; F - Overall significance of regression.

The entire period observed, or 38 hunting seasons, showed a low level of prediction. This would mean that the fox cull and numbers have no effect on brown hares, which is known not to be true.

Knowing that there was a change in fox population dynamics after the rabies vaccination, the same analysis was carried out, excluding the period after 2010. In this sample, the much greater effect of the predictor on the dependent variable is evident (Table 2). $\mathrm{R}^{2}$ indicates how much of the total variation in the dependent variable may be explained by the independent variable. The fox cull explains $25.9 \%$ of the variability of the dependent variable, the brown hare numbers, when looking at this period of 33 hunting seasons. In this example, the influence of the variable is statistically significant $\mathrm{F}=12.179, \mathrm{P}=0.001$. 
I. Ponjiger et al.: The dynamics of red fox (Vulpes vulpes) and brown hare (Lepus europaeus) populations in the Vojvodina region (Serbia) in relation to rabies vaccination

Taking into account that in 1992 there was a significantly lower fox cull for the reasons mentioned above, it was excluded in order to have a more realistic sample. With this sample consisting of 32 hunting seasons, linear regression established that the fox cull may statistically significantly predict the brown hare numbers $\mathrm{F}=16.026, \mathrm{P}=0.000$, and that the fox cull accounted for $32.6 \%$ of the explained variability in the brown hare population.

\section{Discussion}

The average hare density in the Vojvodina region was 12.6 individuals/100 ha. This value corresponds well with most European countries, as well as neighbouring Croatia, where the north-western population with similar habitat conditions ranges from 13 to 20.3 individuals/100 ha (PINTUR et al., 2006).

The red fox is the most common predator in Serbia and inhabits all types of ecosystems and habitats (ĆIROVIĆ, 2000). In 2010 nationwide vaccination against rabies was carried out. During the second half of 2010 and the beginning of 2011 bait containing the vaccine was dispersed by air, being dropped over entire territory of Serbia (http://www.vet.minpolj.gov.rs). The vaccination was carried out by means of dispersal of bait over the entire territory, twice a year (spring and autumn). In 2010/11, 20 pieces of bait per $\mathrm{km}^{2}$ and in 2011/2012, 23 pieces of bait per $\mathrm{km}^{2}$ were dispersed (MIĆOVIĆ et al., 2012). A decline in the number of rabid foxes in Serbia was detected after the vaccination in the period from 2006 to 2012. In 2006 there were 176 cases. The highest number was detected in 2008, when there were 191 cases. After the vaccinations in 2011 and 2012, there were 35 and 8 cases respectively (MAKSIMOVIĆ ZORIĆ et al., 2013). This led to the conclusion that the rabies infection had been contained. Consequently, red fox numbers have increased significantly since then.

The application of vaccines has been recognised as a major factor in the increase of red fox numbers since rabies is considered to be the one of the main factors in limiting the fox population. This was confirmed in Poland, where a drastic increase in the fox population was observed after vaccination (KAMIENIARZ et al., 2008; SMRECZAK and ŻMUDZIŃSKI, 2009). A similar pattern was seen in Slovakia where in the last 40 years the annual fox cull has doubled and the number of brown hare has decreased by more than $60 \%$ in this period (SLAMEČKA et al., 2013). Rabies epidemics have been associated with considerable reductions in host populations by up to 50\% (WANDELER et al., 1974). In the absence of rabies, the fox population increases (ANDERSON et al., 1981). In the Saarland from 1968 to 1974 there was a sharp rise in the number of hares shot, directly associated in time with a sharp reduction in the numbers of foxes, as a result of rabies (MARTINI, 1983). Also, a sharp rise in the fox cull was recorded in West Germany in the years following the rabies vaccination (KNAUER et al., 2010). 
I. Ponjiger et al.: The dynamics of red fox (Vulpes vulpes) and brown hare (Lepus europaeus) populations in the Vojvodina region (Serbia) in relation to rabies vaccination

Although official numbers are not available, reports from most hunting ground managers are similar in terms of the increase in fox numbers. However, while the number of red foxes increased dramatically following the vaccination, the average cull in Vojvodina in 2010-2015 remained nearly the same as in previous years (Fig. 1). This is considered disastrous since the fox population is on the rise. A study in Poland (BOMBIK et al., 2014) showed that even intensive hunting does not give the required results. With exploitation levels at over $60 \%$ the fox population still was not contained and did not show signs of a decline. Given that in the Vojvodina region the fox cull has remained the same, the consequences are starting to show for certain types of small game, including brown hares, which has been shown in this research.

\section{Conclusion}

This paper intended to show the following: a) that the fox population has increased drastically since the rabies vaccination, and b) that as a consequence, the brown hare population has decreased. Since the 2010 vaccination, the statistical balance in the fox cull and the numbers of brown harehas been lost. This may be attributed to the drastic increase in the fox population, as confirmed by reports from hunting ground managers. Also, this shows that the rabies vaccination has led to a rapid increase in the fox population in the Vojvodina region.

Hunting organisations, for the most part, do not encourage or reward predator hunting. Hunters themselves mainly do not have the motivation or they lack interest in hunting predators, and simply go on to hunt other types of game. While, this does not damage the game funds, avoidance of predator hunting leads to a disturbance in the balance of numbers of small game. Also, in the last decade the number of hunters in Serbia has been decreasing steadily. Thus, taking all these factors into account, the negative trend will continue if the current practice continues.

Considering the brown hare population trends and the significant influence that the numbers of red foxes have, it is crucial to monitor and keep track of the changes in population dynamics. Taking into account all the factors influencing the number of hare abundance and recent changes, such as the rabies vaccination, it is necessary to keep track of these changes and respond accordingly. On the basis of the hunting bag data it was shown that where fox numbers were reduced, the number of hares increased and vice versa (LINDSTRÖM et al. 1994). An increase in the red fox cull is recommended in order to achieve a balanced habitat and preserve the vulnerable species that are directly affected, such as hares, partridges and pheasants (BOMBIK et al. 2005; BOMBIK et al. 2009).

So far, the results of the vaccination of red fox have been catastrophic in some areas. While the spread of rabies is under control, the red fox population has increased dramatically. In this case it may be seen that it has had a serious impact on the numbers of 
I. Ponjiger et al.: The dynamics of red fox (Vulpes vulpes) and brown hare (Lepus europaeus) populations in the Vojvodina region (Serbia) in relation to rabies vaccination

brown hare, but it also impacts other species as well. In order to maintain the balance in the ecosystem, it necessary to keep the red fox population under control and increase the cull in the coming years. In this way, small game populations have a chance to recover.

\section{Acknowledgements}

The authors are grateful to the Ministry of Education, Science and Technological Development of the Republic of Serbia which funded this study within the Project 176020.

\section{References}

ANDERSON, R. M., H. C. JACKSON, R. M. MAY, A. M. SMITH (1981): Population dynamics of fox rabies in Europe. Nature, 289, 765-771.

DOI: $10.1038 / 289765 \mathrm{a} 0$

BEUKOVIĆ, M., D. BEUKOVIĆ, Z. POPOVIĆ, P. PERIŠIĆ (2009): Number and usage level dynamics of population brown hare (Lepus Europaeus) round of river Tisa in Bačka district. Zbornik naučnih radova Instituta PKB Agroekonomik 15, 173-179 (in Serbian).

DOI: $10.2298 / \mathrm{avb} 1301111 \mathrm{~b}$

BEUKOVIĆ, M., D. BEUKOVIĆ, Z. POPOVIĆ, N. ĐORĐEVIĆ, M. ĐORĐEVIĆ, (2013): Impact of climatic factors to the percentage of young in the population of brown hare (Lepus europaeus Pallas) in the Bačka district. Acta Vet. Beograd 63, 111-122.

DOI: $10.2298 / \mathrm{avb} 1301111 \mathrm{~b}$

BOMBIK, E., A. WYSOKIŃSKA, S. KONDRACKI (2005): Estimation of changes in the numbers and exploitation of hare population (Lepus europaeus Pall.) in the Mazovian province. Rocz. Nauk. PTZ. 1, 397-404 (in Polish).

BOMBIK, E., A. WYSOKIŃSKA, K. GÓRSKI, S. KONDRACKI (2009): The dynamics of changes of partridge population (Perdix perdix L.) in the hunting regions of the middle eastern Poland in the years 1998-2007. Rocz. Nauk. PTZ. 5, 229-237.

BOMBIK, E., A. WYSOKIŃSKA, K. GÓRSKI, S. KONDRACKI, A. PAPROCKA, P. JAKUBCZAK (2014): The dynamics of fox (Vulpes vulpes L.) populations in selected hunting regions of the central-eastern Poland in relation to effectiveness of rabies vaccination. Vet Zootec. 68, 9-15.

ĆIROVIĆ, D. (2000): Morphological variability and biogeographical status of fox populations (Vulpes vulpes Linnaeus, 1758) in Vojvodina. Magister thesis, Faculty of Biology, University of Belgrade (in Serbian).

DONCASTER, C. P., C. R. DICKMANN, D. W. MACDONALD (1990): Feeding ecology of red foxes in the city of Oxford, England. J. Mammal. 71, 188-194.

DOI: $10.2307 / 1382166$

GORETZKI, J., K. DOBIAS K. H. PAUSTIAN (1999). Investigating the situation of the Great Bustard in the future protection areas Belziger Landschaftswiesen and Havelländisches Luch. Beiträge zur Jagd und Wildforschung 24, 291-306 (in German). 
I. Ponjiger et al.: The dynamics of red fox (Vulpes vulpes) and brown hare (Lepus europaeus) populations in the Vojvodina region (Serbia) in relation to rabies vaccination

GOSZCZYŃSKI, J., M. MISIOROWSKA, S. JUSZKO (2008): Changes in the density and spatial distribution of red fox dens and cub numbers in central Poland following rabies vaccination. Acta Theriol. 53, 121-127.

DOI: $10.1007 / \mathrm{bf03194245}$

HELL, P., P. FĹAK, J. SLAMEČKA (1997): The correlation between the hunting bag records of red deer, roe deer, and brown hare with those of their primary predators in Slovakia in the years 1968-1995. Zeittschrift für Jagdwissenschaft 43, 73-84 (in German).

DOI: $10.1007 / \mathrm{bf} 02241415$

JĘDRZEJEWSKI, W., B. JĘDRZEJEWSKA, A. SZYMURA (1989): Food niche overlaps in a winter community of predators in the Bialowieza Primeval Forest, Poland. Acta Theriol. 34, 487-496.

DOI: $10.4098 /$ at.arch.89-48

JENNINGS, N. V., R. K. SMITH, K. HACKLÄNDER, S. HARRIS, P. C. L. WHITE (2006): Variation in demography, condition, and dietary quality of hares (Lepus europaeus) from highdensity and low-density populations. Wildlife Biol. 12, 179-190.

DOI: 10.2981/0909-6396(2006)12[179:vidcad]2.0.co;2

KAMIENIARZ, R., A. KRYŃSKI, T. WIELICH (2008): Results of red fox vaccination against rabies in relation to this species population in Wielkopolska. Med Weter. 64, 318-321.

KNAUER, F., H. KÜCHENHOFF, S. PILZ (2010): A statistical analysis of the relationship between red fox Vulpes vulpes and its prey species (grey partridge Perdix perdix, brown hare Lepus europaeus and rabbit Oryctolagus cuniculus) in Western Germany from 1958 to 1998. Wildlife Biol. 16, 56-65.

DOI: $10.2981 / 07-040$

KRAPINEC, K., A. LAMPE, I. KOVAČ, K. SEVERIN, D. KONJEVIĆ, K. PINTUR (2010): Red fox (Vulpes vulpes) and stone marten (Martes foina) predation of brown hare. Zbornik radova 45. hrvatskog i 5. međunarodnog simpozija agronoma, Poljoprivredni fakultet u Osijeku, 973977.

DOI: $10.1078 / 1616-5047-00021$

LINDSTROM, E. (1989): Food limitation and social regulation in a red fox population. Holarctic Ecol. 12, 70-79.

LINDSTRÖM, E. R., H. ANDRÉN, P. ANGELSTAM, G. CEDERLUND, B. HÖRNFELDT, L. JÄDERBERG, P. A. LEMNELL, B. MARTINSSON, K. SKÖLD, J. E. SWENSON (1994): Disease reveals the predator: sarcoptic mange, red fox predation, and prey populations. Ecology 75, 1042-1049.

DOI: $10.2307 / 1939428$

MAKSIMOVIĆ ZORIĆ, J., V. MILIĆEVIĆ, LJ. VELJOVIĆ, T. PETROVIĆ, M. VALČIĆ, B. PLAVŠIĆ, N. VRANJES̆ (2013): Rabies - Epizootiological situation at the teritory of Serbia and countries in the region from 2006. to 2012. Veterinarski glasnik 67, 377-394 (in Serbian). DOI: $10.2298 /$ vetg11306377m 
I. Ponjiger et al.: The dynamics of red fox (Vulpes vulpes) and brown hare (Lepus europaeus) populations in the Vojvodina region (Serbia) in relation to rabies vaccination

MARTINI, H. (1983): The causes of conspicuously larger bags of hare in the Saarland in the hunting seasons $1968 / 69$ to $1974 / 75$ associated with very low numbers of foxes as a result of rabies. Zeitschrift für Jagdwissenschaft. 29, 1-12 (in German).

DOI: $10.1007 / \mathrm{bf02243656}$

MIĆOVIĆ, Z., V. MILIĆEVIĆ, B. PLAVŠIĆ, J. UZELAC, K. TOŠIĆ (2012): Oral vaccination against rabies - monitoring and results. Zbornik radova i kratkih sadržaja. Drugi internacionalni epizootiološki dani. Beograd, Srbija. 283-90 (in Serbian).

PANEK, M., R. KAMIENIARZ (1999): Relationships between density of brown hare Lepus europaeus and landscape structure in Poland in the years 1981-95. Acta Theriol. 44, 67-75.

DOI: 10.4098/at.arch.99-7

PANEK, M., R. KAMIENIARZ, W. BRESIŃSKI (2006): The effect of experimental removal of red foxes Vulpes vulpes on spring density of brown hares Lepus europaeus in western Poland. Acta Theriol. 51, 87-193.

DOI: $10.1007 / \mathrm{bf03192670}$

PINTUR, K., N. POPOVIĆ, A. ALEGRO, K. SEVERIN, A. SLAVICA, E. KOLIĆ (2006): Selected indicators of brown hare (Lepus europaeus Pallas, 1778) population dynamics in northwestern Croatia. Vet. arhiv 76, 199-209.

POPOVIĆ, Z., M. BEUKOVIĆ, D. BEUKOVIĆ (2014): Management measures in brown hare population in various habitats in Serbia. Proceedings of the International Symposium on Animal Science 2014, September 2014, Belgrade-Zemun 428-437.

SCHMIDT, N. M., T. ASFERG, M. FORCHHAMMER (2004): Long-term patterns in European brown hare population dynamics in Denmark: effects of agriculture, predation and climate. BMC Ecol. 4, 15.

SLAMEČKA, J., P. HELL, R. JURČÍK (1997): Brown hare in the west Slovak lowland. Acta Sci. Nat. Brno. 31, 1-115.

SLAMEČKA, J., T. SLÁDEČEK, J. GAŠPARÍK, R. JURČÍK, L. PAULE (2013): Actual status and development of European brown hare (Lepus europaeus) population in Slovakia. Second international symposium on hunting "Modern aspect of sustainable management of game" 1720.10.2013. Novi Sad, Serbia. Proceedings 48-53.

SMITH, R. K., N. VAUGHAN JENNINGS, S. HARRIS (2005): A quantitative analysis of the abundance and demography of European hares Lepus europaeus in relation to habitat type, intensity of agriculture and climate. Mammal Rev. 35, 1-24.

DOI: 10.1111/j.1365-2907.2005.00057.x

SMRECZAK, M., J. F. ŻMUDZIŃSKI (2009): Rabies in Poland in 2007. Med Weter. 65, 617-620.

ŠELMIĆ, V. (1996): Fox population density as a factor in the spread of sylvatic rabies. Simpozijum o besnilu, Pasterov zavod, Novi Sad. 85-92 (in Serbian).

ŠELMIĆ, V. (1997): Brown hare and partridge in the modern agro-ecosystem. Zbornik radova Lovački savez Vojvodine, Novi Sad. 1-32 (in Serbian). 
I. Ponjiger et al.: The dynamics of red fox (Vulpes vulpes) and brown hare (Lepus europaeus) populations in the Vojvodina region (Serbia) in relation to rabies vaccination

TAPPER, S. C., G. R. POTTS, M. H. BROCKLESS (1996): The effect of an experimental reduction in predation pressure on the breeding succes and population density of grey partridges Perdix perdix. J. Appl. Ecol. 33, 965-978.

DOI: $10.2307 / 2404678$

VAPA, M., V. ŠELMIĆ (1997): The current state and future of the brown hare. Zbornik radova Lovački savez Vojvodine, Novi Sad. 33-45 (in Serbian).

WANDELER, A., G. WACENDÖRFER, U. FÖRSTER, H. KREKEL, W. SCHALE, J. MÜLLER, F. STECK (1974): Rabies in wild carnivores in Central Europe. I. Epidemiological studies. Zbl. Vet. Med. B. 21, 735-756.

DOI: $10.1111 /$ j.1439-0450.1974.tb00478.x

Received: 16 April 2018

Accepted: 17 April 2019

PONJIGER, I., Z. RISTIĆ, V.MARKOVIĆ, M. MATEJEVIĆ, M. KOVAČEVIĆ: Utjecaj cijepljenja protiv bjesnoće na dinamiku populacija lisice (Vulpes vulpes) i zeca običnog (Lepus europaeus) u Vojvodini, Republika Srbija. Vet. arhiv 89, 839850, 2019.

\section{SAŽETAK}

Na temelju raspoloživih podataka iz 1978. do 2015. u Autonomnoj pokrajini Vojvodini (Republika Srbija) analizirana je dinamika populacija lisice (Vulpes vulpes Linneus, 1758) i zeca običnog (Lepus europaeus Pallas, 1778). U obzir je uzet odstrel lisice kao čimbenika koji utječe na brojnost zečeva. U tom je razdoblju tijekom redovnih lovova odstrijeljeno ukupno 399976 lisica, a godišnji prosjek iznosi 10526 (SD = 2985). Podaci proljetnog prebrojavanja zečeva pokazuju fluktuacije tijekom istraživačkog razdoblja i trend opadanja njihova broja. Za istraživanje je odabrana lisica kao najbrojniji grabežljivac na ovom području, s najviše utjecaja na zeca običnog. Također, tijekom 2010. godine provedeno je cijepljenje protiv bjesnoće diljem zemlje, što je dovelo do porasta broja lisica. No dok je broj lisica porastao, u sljedećim je godinama odstrel ostao gotovo jednak. Analize odnosa između zeca običnoga i lisice od 1978. do 2009. i od 2010. do 2015. pokazuju znakovitu razliku. Ovo istraživanje pokazuje da je broj lisica znatno povećan nakon kampanje cijepljenja protiv bjesnoće. Slijedom toga ovo je važan čimbenik koji utječe i na populaciju zeca. Također, očito je da se odstrel lisica mora povećati kako bi se održala prirodna ravnoteža.

Ključne riječi: zec obični; lisica; bjesnoća; korelacija 